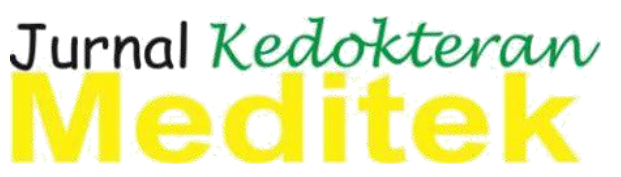

\title{
Uji Kadar Likopen dan Aktivitas Antioksidan pada Buah Tomat (Solanum lycopersicum)
}

\section{Fanny Mariska Sima1 ${ }^{1}$, Esther Sri Majawati² ${ }^{2}$ dan Hendrik Kurniawan ${ }^{3}$}

\author{
${ }^{1}$ Fakultas Kedokteran dan Ilmu Kesehatan, Universitas Kristen Krida Wacana, Jakarta, \\ Indonesia. \\ ${ }^{2}$ Departemen Parasit, Fakultas Kedokteran dan Ilmu Kesehatan, Universitas Kristen Krida \\ Wacana, Jakarta, Indonesia. \\ ${ }^{3}$ Departemen Biokimia, Fakultas Kedokteran dan Ilmu KesehatanUniversitas Kristen Krida \\ Wacana, Jakarta, Indonesia. \\ Alamat korespondensi : esther.majawati@ukrida.ac.id
}

\begin{abstract}
Abstrak
Stres oksidatif, yaitu ketidakseimbangan antara radikal bebas dan zat antioksidan dalam tubuh, banyak dikaitkan dengan kejadian atherosklerosis, inflamasi, kanker, dan proses penuaan. Beban stres oksidatif yang meningkat karena pengaruh pola makan yang tinggi lemak dan polusi menyebabkan tubuh membutuhkan asupan antioksidan dari luar berupa suplemen atau bahanbahan makanan yang mengandung antioksidan misalnya tomat (Solanum lycopersicum). Buah tomat memiliki kandungan likopen yang cukup tinggi yang kemampuannya mengendalikan radikal bebas 100 kali lebih efisien dibanding vitamin E dan 12500 kali dari pada glutathione peroksidase (enzim antioksidan endogen dalam tubuh). Tujuan dari penelitian ini adalah untuk menentukan aktivitas antioksidan buah tomat dan untuk mengetahui kadar likopen dalam tomat. Aktivitas antioksidan ditentukan secara spektrofotometri, yaitu dengan métode DPPH. Kadar likopen dalam buah tomat ditentukan berdasarkan absorbansi dan nilai absorbansi spesifiknya. Dari hasil penelitian ini didapatkan kadar antioksidan dengan metode DPPH/ IC50 buah tomat adalah $60 \mu \mathrm{g} / \mathrm{ml}$ termasuk dalam antioksidan kuat, dan kadar likopen dalam buah tomat ada sebesar $3.42 \mathrm{mg} / \mathrm{kg}$ sampel segar. Dapat disimpulkan bahwa buah tomat mengandung kadar antioksidan
\end{abstract}

Kata kunci : aktivitas antioksidan, likopen, tomat (Solanum lycopersicum)

\section{Evaluation of Licopene Content and Antioxidant Activity in Tomato Fruit (Solanum lycopersicum)}

\begin{abstract}
Oxidative stress, a condition of imbalanced free radicals and antioxidant in our body has long been associated with the occurrence of atherosclerosis, inflammation, cancer, and aging. Increased oxidative stress, due to high fat intake and pollution requires the consumption of antioxidant compounds from food or food supplements. Tomatoes (Solanum lycopersicum) has been known to have a high content of lycopene that is capable of controlling free radicals 100 times more efficiently than vitamin E and 12500 times than glutathione peroxidase which is an endogenous antioxidant enzyme. The purpose of this study was to determine lycopene content and antioxidant activity of tomatoes. Antioxidant activity was determined spectrophotometrically based on a DPPH method, whereas lycopene content was determined based on its absorbance and its specific absorbance. This study found that the IC50 of tomatoes was $60 \mu \mathrm{g} / \mathrm{ml}$ which is classified as strong antioxidant, and lycopene content in tomatoes was $3.42 \mathrm{mg} / \mathrm{kg}$ fresh sample. Therefore, this study may conclude tomatoes as a good source of antioxidant.
\end{abstract}

Keywords: antioxidant activity, lycopene, tomato (Solanum lycopersicum) 


\section{Pendahuluan}

Radikal bebas merupakan suatu senyawa yang dapat merugikan tubuh yang dapat diproduksi dari metabolisme sel normal (in situ) atau dari luar misalnya polusi, asap rokok, radiasi, dan lainnya. ${ }^{1}$ Radikal bebas yang terlalu banyak dalam tubuh dapat menyebabkan stres oksidatif yang mendukung terjadinya banyak proses, misalnya atherosklerosis, kondisi inflamasi, kanker, dan proses penuaan. ${ }^{2}$ Di dalam tubuh terdapat senyawa yang mampu menetralisir senyawa radikal bebas yang disebut dengan antioksidan enzimatis misalnya superoksida dismutase (SOD), glutathione peroksidase, dan katalase; serta antioksidan nonenzimatis yang terbagi jadi dua kelompok yaitu antioksidan larut lemak misalnya tokoferol, karotenoid, flavonoid, quinon, dan bilirubin, antioksidan yang larut air misalnya asam askorbat, asam urat, protein pengikat logam, dan protein pengikat heme. $^{3,4}$

Stres oksidatif dapat menyebabkan terjadinya penyakit kardiovaskular karena akan mengakibatkan terjadinya peroksidasi lipid sehingga memicu proses penyempitan pembuluh darah (atherosklerosis); kanker karena dapat menginduksi mutasi pada gen; neuropati (keadaan hiperglikemik) akan mengakibatkan perubahan pada mitokondria sehingga memicu terjadinya kematian sel yang terprogram (apoptosis); penyakit neurodegeneratif yang berhubungan dengan usia, sehingga menginduksi mutasi dan disfungsi mitokondria; serta kelainan pada fetus, dimana semakin bertambahnya usia kandungan, plasenta akan ikut membesar sehingga transfer oksigen ke janin akan semakin banyak, tetapi seiring dengan pembesaran plasenta tersebut maka resiko untuk terjadinya stres oksidatif akan meningkat dan dapat memicu kematian sel terprogram (apoptosis). ${ }^{5-11}$

Buah tomat memiliki kandungan antioksidan (likopen) yang cukup tinggi yang kemampuannya mengendalikan radikal bebas 100 kali lebih efisien dibanding vitamin E dan 12500 kali dari pada gluthation peroksidase. Buah tomat ini merupakan salah satu tanaman yang banyak dan mudah untuk dicari di Indonesia. ${ }^{12-13}$ Likopen adalah antioksidan yang efektif dan non-provitamin-A dengan kemampuan untuk memerangkap radikal peroksil di antara berbagai karotenoid, serta memiliki perlindungan biomolekul dari kerusakan oksidatif. Likopen sendiri sudah terdaftar menjadi zat yang mampu bekerja sebagai neuroprotektif, antiinflamasi, penambah kognitif. ${ }^{14}$ Diet bebas likopen atau tomat mengakibatkan hilangnya likopen dan menunjukkan peningkatan oksidasi lipid, sedangkan suplementasi makanan dengan likopen selama 1 minggu menyebabkan meningkatnya kadar likopen serum, mengurangi tingkat oksidasi lipid endogen, oksidasi protein, oksidasi lipoprotein dan DNA. Likopen memberikan perlindungan terhadap beberapa penyakit kronik dengan menghilangkan atau mengurangi stress oksidatif. Likopen melindungi lipis, DNA, dan Protein terhadap oksidasi, yang mana hasil oksidasi produk tersebut dianggap memiliki peran kunci dalam kanker dan berbagai penyakit kronis dan juga telah dilaporkan meningkat dalam kondisi penyakit kronis secara signifikan. ${ }^{15}$ Kerusakan sel endotel oleh stres oksidatif merupakan komponen penting untuk etiologi aterosklerosis, likopen menurunkan oksidatif cedera sel endotel yang diinduksi oleh $\mathrm{H} 2 \mathrm{O} 2$, melemahkan ekspresi p53 dan caspase-3 mRNA dalam sel yang terluka, dan mengurangi apoptosis sel yang terluka sehingga dapat menurunkan resiko terjadinya atorisklerosis penyakit kardiovaskular. Selain itu, enzim endogen antioksidan seperti superoksida dismutase, glutation peroksidase dan glutation reduktase juga dapat distimulasi oleh likopen. Sel-sel yang dilindungi oleh likopen menunjukkan reduksi kuat dalam peroksidasi lipid, yang menunjukkan likopen dapat melindungi sel mamalia terhadap kerusakan membran dan mungkin memaikan peran perlindungan terhadap pembentukan tumor yang terkair dengan kerusakan stress oksidatif. ${ }^{16}$

Oleh sebab itu, peneliti ingin melakukan sebuah penelitian mengenai 
kadar likopen dan aktivitas antioksidannya pada buah tomat, dimana likopen ini merupakan suatu karotenoid pigmen merah terang yang banyak ditemukan dalam buah tomat dan buah-buahan lain yang berwarna merah. ${ }^{17-18}$

\section{Metodologi Penelitian Alat dan Bahan}

Tomat segar, larutan DPPH dan pelarut oragnik untuk ektraksi (metanol, ethanol, n-heksana, dan aquadest); blender, spektrofotometer Uv-Vis, dan peralatan gelas kimia.

\section{Metodologi Penelitian Penyiapan Ekstrak Tomat}

Sembilan buah tomat segar (1400 g) diblender, kemudian disaring menggunakan saringan. Air saringan tomat disaring beberapa kali menggunkan kertas saring hingga diperoleh air berwarna kuning (air tomat). ${ }^{3}$ Selama pengerjaan, air saringan tomat ditempatkan pada erlenmeyer yang pada bagian luar dilapisi dengan aluminium foil.

\section{Penentuan Aktivitas Antioksidan dengan Metode DPPH}

Aktifitas antioksidan jus buah tomat ditentukan dengan metode DPPH. Disiapkan berbagai konsentrasi jus tomat dalam tabung reaksi, yaitu dengan memipet jus tomat sebanyak $0 \mu \mathrm{L}, 10 \mu \mathrm{L}, 20 \mu \mathrm{L}, 30 \mu \mathrm{L}, 40 \mu \mathrm{L}$, $50 \mu \mathrm{L}$, dan $60 \mu \mathrm{L}$. Ke dalam masing-masing tabung ditambahkan methanol hingga volume total menjadi $3000 \mu \mathrm{L}$ pada setiap tabung reaksi. Larutan campuran methanol dan air tomat kemudian dikocok agar menyatu, kemudian ke dalam masingmasing tabung tersebut ditambahkan 1000 $\mu \mathrm{L}$ cairan DPPH dan divortex kembali. Seluruh tabung dilapisi dengan alumunuim foil, dan diletakan di tempat gelap selama 30 menit. Setelah inkubasi, absorbansi diukur dengan menggunakan spektrofotometer UvVis pada panjang gelombang $517 \mathrm{~nm}$. Persen inhibisi dihitung dengan rumus $:^{3}$

Daya antioksidan $=\{$ (absorban blanko absorban sampel) / Absorban blanko\} x 100 $\%$

\section{Penentuan Kadar Likopen}

Untuk menentukan kadar likopen diambil 5 gram sampel dari lapisan nonpolar yang terbentuk pada jus tomat diatas dan dimasukan ke dalam baker glass yang dilapisi dengan alumunium foil. Setelah itu, 5 gram sampel tomat tersebut dilarutkan dalam $50 \mathrm{ml}$ campuran heksana, aseton, dan etanol dengan perbandingan 2:1:1 $\mathrm{v} / \mathrm{v}$, dan dikocok dengan magnetik stirer selama 30 menit. Kemudian larutan tersebut dipindahkan ke corong pemisah, lalu ditambahkan $10 \mathrm{ml}$ aquadest, dan dikocok lagi dengan magnetik stirer selamat 15 menit. Setelah itu diambil lapisan non-polar (bagian atasnya) dipisahkan dengan cara membuka bagian bawah corong agar lapisan polarnya terbuang, dan ditambahkan pelarut organik, selanjutnya diukur dengan menggunakan spektrofotometer Uv-Vis dengan panjang gelombang maksimal 417 $\mathrm{nm}$. Dan dihitung kadar likopennya dengan rumus : ${ }^{3}$

$$
\mathrm{C}=\mathrm{A} /(\mathrm{E} 1 \% 1 \mathrm{~cm} \times \mathrm{B})
$$

Dimana :C : konsentrasi $(\mathrm{g} / 100 \mathrm{~mL}), \mathrm{A}$ :

Absorbansi, B : ketebalan cuvette $(\mathrm{cm})$,

$$
\text { E1\%1cm: } 3450
$$

*E1\% $1 \mathrm{~cm}$ mengacu pada absorbansi $1 \mathrm{~cm}$ lapisan larutan yang berkonsentrasi pada panjang gelombang yang ditentukan dan absorbansi sinar dari likopen adalah $3450 .{ }^{19}$

\section{Hasil}

Sebanyak $1400 \mathrm{~g}$ buah tomat yang diblender dihasilkan jus tomat sebanyak $1000 \mathrm{ml}$. Hasil penyaringan menggunakan kertas saring diperoleh ekstrak tomat sebanyak $125 \mathrm{ml}$. 
Tabel 1. Data Absorbansi Likopen dengan Pelarut Metanol

\begin{tabular}{lccc}
\hline \multicolumn{1}{c}{ Volume sampel } & Tabung 1 & Tabung 2 & Tabung 3 \\
\hline $\begin{array}{l}0 \mu \mathrm{L} \text { (blanko) } \\
\text { (konsentrasi awal) }\end{array}$ & 1,250 & 1,300 & 1,285 \\
$10 \mu \mathrm{L}$ & 1,135 & 1,117 & \\
$20 \mu \mathrm{L}$ & 1,017 & 1,032 & 1,124 \\
$30 \mu \mathrm{L}$ & 0,848 & 0,937 & 0,919 \\
$40 \mu \mathrm{L}$ & 0,873 & 0,804 & 0,873 \\
$50 \mu \mathrm{L}$ & 0,721 & 0,714 & 0,754 \\
$60 \mu \mathrm{L}$ & 0,645 & 0,594 & 0,672 \\
\hline
\end{tabular}

Tabel 2. Data Persentase Inhibisi Antioksidan pada Tomat terhadap DPPH

\begin{tabular}{lcccc}
\hline Volume sampel & Tabung 1 & Tabung 2 & Tabung 3 & Rata-rata \\
\hline $0 \mu \mathrm{L}$ & 9,200 & 14,077 & 12,868 & 12,048 \\
$10 \mu \mathrm{L}$ & 18,640 & 20,615 & 16,977 & 18,744 \\
$20 \mu \mathrm{L}$ & 32,160 & 27,923 & 28,760 & 29,614 \\
$30 \mu \mathrm{L}$ & 30,160 & 38,154 & 32,326 & 33,546 \\
$40 \mu \mathrm{L}$ & 42,320 & 45,077 & 41,550 & 42,982 \\
$50 \mu \mathrm{L}$ & 48,400 & 54,308 & 47,907 & 50,205 \\
$60 \mu \mathrm{L}$ & & & & \\
\hline
\end{tabular}

\section{Aktivitas antioksidan Jus buah tomat}

antioksidan menggunakan aktivitas spektrofotometri Uv-Vis dengan panjang gelombang $517 \mathrm{~nm}$, diperoleh kurva baku yaitu $\mathrm{Y}=0.775 \mathrm{x}+3.8702$ dengan garis linier $\mathrm{R}^{2}=0.9993$.

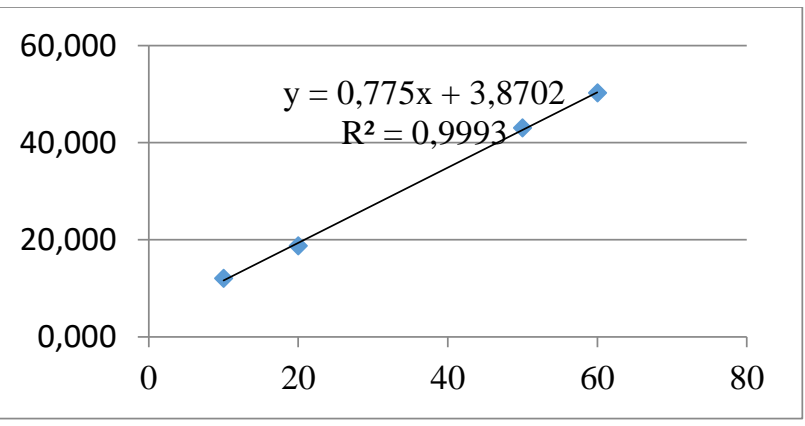

Gambar 1. Kurva Aktivitas Antioksidan

Larutan Likopen. Nilai R yang mendekati 1 menunjukan persamaan regresi tersebut adalah linier dan simpangan baku yang kecil menunjukkan ketepatan yang cukup tinggi. Aktivitas antioksidan dinyatakan dengan nilai IC50 (Inhibition
Concentration) yang merupakan konsentrasi suatu zat antioksidan yang dapat menyebabkan 50\% DPPH kehilangan karakter radikal atau konsentrasi suatu zat antioksidan yang memberikan persentase penghambatan $50 \%$. Nilai $\mathrm{IC}_{50}$ dihitung berdasarkan persamaan regresi linier yang didapat pada Gambar $1(\mathrm{Y}=0.775 \mathrm{x}+$ 3.8702). Dari persamaan ini diperoleh nilai $\mathrm{IC}_{50}$ sebesar $59.52(60 \mu \mathrm{g} / \mathrm{ml})$.

\section{Kadar Likopen dalam Jus Tomat}

Hasil absorbansi ekstrak likopen dari jus tomat terlihat pada Tabel 3 .

Tabel 3. Data Absorbansi Kadar Likopen

\begin{tabular}{cc}
\hline Tabung & Absorbansi \\
\hline Tabung 1 & 0,31 \\
Tabung 2 & 0,34 \\
Tabung 3 & 0,33 \\
Rata-rata Absorbansi & 0,33 \\
\hline
\end{tabular}


Kadar likopen ditentukan menggunakan persamaan: $\mathrm{C}=\mathrm{A} /(\mathrm{E} 1 \% 1 \mathrm{~cm} \times \mathrm{B})$, dimana nilai $\mathrm{E} 1 \% 1 \mathrm{~cm}$ dan $\mathrm{B}$ masing-masing adalah 3450 dan $1 \mathrm{~cm}$.

Diperoleh konsentrasi likopen sebesar $=0.00009565 \mathrm{~g} / 100 \mathrm{ml}$ $=3,42 \mathrm{mg} / \mathrm{kg}$ sampel segar

\section{Pembahasan}

Dalam penelitian ini metode yang digunakan adalah metode dengan DPPH atau a,a-diphenyl-B picrylhydrazyl $\left(\mathrm{C}_{18} \mathrm{H}_{12} \mathrm{~N}_{5} \mathrm{O}_{6} ; \mathrm{M}=394.33\right)$ merupakan cara yang sering dipakai untuk mengevaluasi potensi antioksidan dari suatu bahan. Dikembangkan oleh Blois (1958), kinerjanya berdasarkan pengukuran dari kapasitas scavenging dari antioksidan tersebut. Electron aneh dari DPPH akan direduksi oleh atom hydrogen yang diberikan oleh antioksidan. DPPH merupakan radikal bebas yang stabil berdasarkan delokalisasi electron cadangan atas molekul secara keseluruhan. Sehingga molekul DPPH tidak dimerise seperti kebanyakan radikal bebas lainnya. ${ }^{20} \mathrm{DPPH}$ memberikan serapan kuat pada panjang gelombang $517 \mathrm{~nm}$ dengan warna violet gelap, dengan tertangkapnya radikal bebas oleh antioksidan akan menyebabkan hilangnya warna yang sebanding dengan jumlah elektron yang diambil sehingga menjadi warna kuning. Perubahan tersebut dapat diukur dengan spektrofotometer dan diplotkan terhadap konsentrasi penurunan intensitas warna yang terjadi disebabkan berkurangnya ikatan rangkap terkonjugasi pada DPPH. Antioksidan akan memberikan senyawa hidrogen pada DPPH sehingga tereduksi menjadi DPPH-H (1,1-difenil-2pikrilhidrazin). ${ }^{13,21}$

Dalam penelitian ini menggunakan methanol sebagai pelarut dikarenakan likopen merupakan zat hidrofobik kuat sehingga tidak larut dalam air, tetapi larut pada pelarut organik misalnya n-heksana, methanol, ethanol, dll). Kadar likopen dapat diukur dengan cara memisahkan lapisan polar dan nonpolar dari hasil ekstrasi makanan yang mengandung tomat, dengan cara mengukur kadar likopen pada lapisan non-polar dengan menggunakan spektrofotometer UV-Vis dengan gelombang maksimum $417 \mathrm{~nm} .^{22}$

Dalam penelitian ini menggunakan methanol sebagai pelarut dikarenakan likopen merupakan zat hidrofobik kuat sehingga tidak larut dalam air, tetapi larut pada pelarut organik seperti n-heksana, methanol, ethanol, dll). Pada tabel 2 dari setiap volume sampel yang dirata-rata dan disubsitusi kedalam persamaan liner kurva standar (gambar 1) yang menghasilkan $\mathrm{R}^{2}=$ 0.9993. Nilai $R$ yang mendekati 1 membuktikan bahwa persamaan rergesi tersebut adalah linier dan simpangan baku yang kecil menunjukkan ketepatan yang cukup tinggi. Setelah disubsitusi menghasilkan nilai konsentrasi inhibisi 60 $\mu \mathrm{g} / \mathrm{ml}$ dimana sesuai dengan kategori aktivitas antioksidannya, termasuk dalam antioksidan kuat karena nilai IC50 $=50-100$ $\mu \mathrm{g} / \mathrm{ml}$.

Berdasarkan rekomendasi asupan harian likopen yaitu 3.35-4.82 mg likopen perhari, maka untuk mencukupi asupan harian likopen hanya dibutuhkan mengonsumsi $1 \mathrm{~kg}$ buah tomat perhari. ${ }^{23}$

\section{Simpulan}

Dari hasil penelitian yang tekah dilakukan dapat diambil kesimpulan sebagai berikut :

1. Ekstrak buah tomat dengan menggunakan metanol memiliki kemampuan meredam radikal bebas (DPPH) dengan IC 50 $=60$ $\mu \mathrm{g} / \mathrm{ml}$, dimana kadar IC 50 ini menunjukkan bahwa tomat memiliki aktivitas antioksidan yang kuat terhadap DPPH (a,a-diphenyl-B picrylhydrazyl)

2. Selain itu kadar likopen yang terdapat dalam sampel tomat pada penelitian ini adalah $3.42 \mathrm{mg} / \mathrm{kg}$ sampel segar Berdasarkan rekomendasi asupan harian likopen yaitu 3.35-4.82 mg likopen perhari, maka untuk mencukupi asupan harian likopen dibutuhkan mengonsumsil $\mathrm{kg}$ buah tomat perhari. ${ }^{23}$ 


\section{Daftar Pustaka}

1. Pham-Huy LA, He H, Pham-Huy C. Free radicals, antioxidants in disease and health. Int $\mathbf{J}$ Biomed Sci. 2008; 4(2):89-95

2. V lobo, et al. Free radicals, antioxidants and functional foods: impact on human health. Pharmacogn rev. 2010;4(8):118-26

3. Andayani R, Maimunah, Lisawati Y. Penentuan aktivitas antioksidan, kadar fenolat total dan likopen pada buah tomat (Solanum lycopersicum L). J Sains Tek Far. 2008;13(1):31-6

4. Winarsi H. Antioksidan alami dan radikal bebas, potensi dan aplikasinya dalam kesehatan. Yogyakarta: Kanisius ; 2007.h.26-45

5. Ho E, et al, Biological markers of oxidative stress: applications to cardiovascular research and practice. Redox Biology 1. 2013:483-91

6. Noda N, Wakasugi H, Cancer and stress oxidative. JMAJ. 2001; 44(12):535-9

7. Gandhi S, Abramov AY. Mechanism of oxidative stress in neurodegeneration. Oxidative Medicine and Cellular Longevity. 2012:1-7

8. Hosseini A, Abdollahi M. Diabetic neuropathy and oxidative stress: therapeutic perspectives. Oxid Med Cell Longev. 2013;1-7

9. Sandireddy R, et al. Neuroinflammation and oxidative stress in diabetic neuropathy: futuristic strategies based on these targets. International Journal of Endocrinology. 2014:1-5

10. Chopra $\mathrm{M}$, et al, Oxidative stress in diabetic neuropathy: source of reactive oxygen species. Endocrinology Studies. 2012;2(6):22-4

11. Thompson LP, Al-Hazan Y. Impact of oxidative stress in fetal programming. Journal of Pregnancy. 2012:1-5

12. Maong R, Rorong JA, Fatimah F. Aktivitas ekstrak buah tomat (Lycopersicum esculentumMill) sebagai penstabil oksigen singlet dalam reaksi fotooksidasi asam linoleat. Jurnal Mipa Unsrat Online. 2016;5(1):60-4

13. Mu'nisa A. Analisis kadar likopen dan uji aktivitas antioksidan pada tomat asal Sulawesi Selatan. Jurnal Bionature. 2012;13(1):62-6

14. Kumar PVN, Et al. A systematic review on lycopene and its beneficial effects. Biomed \& Pharmacol J. 2017;10(4): 2113-8

15. Metha N, Patani P, Singhvi I. A review on tomato lycopene. IJPSR. 2018; 9(3):916-21

16. Amarowicz R. Lycopene as a natural antioxidant. Eur J Lipid Sci Technol. 2011;113:675-6

17. Novita M, Satriana, Hasmarita E. Kandungan likopen dan karotenoid buah tomat (Lycopersicum pyriforme) pada berbagai tingkat kematangan: pengaruh pelapisan dengan kitosan dan penyimpanan. Jurnal Teknologi Dan Industri Pertanian Indonesia. 2015;7(1):35-9

18. Suwanaruang T. Analyzing lycopene content in fruits. Agriculture and Agricultural Science Procedia. 2016; 11:46-8

19. Socaciu C. Food colorants, chemical and functional properties. USA: CRC Press; 2008.p.57

20. Kedare SB, Singh RP. Genesis and development of DPPH method of antioxidant assay. J Food Sci Technol. 2011;48(4):412-3

21. Sayuti K, Yenrina R. Antioksidan alami dan sintetik. Padang: Andalas University Press; 2015.h.1-15

22. Novelina, Nazir N, Adrian MR. The improvement lycopene availability and antioxidant activities of tomato (Lycopersicum esculentum, mill) jelly drink. Agriculture and Agricultural Science Procedia. 2016; 9:328-34

23. Alda LM, et al. Lycopene content of tomatoes and tomato products. Journal of Agroalimentary and Technologies. 2009;15(4):542 